\title{
Reflections on Legal Language
}

Geraldo Carreiro de Barros

Filho ${ }^{1}$;

Larissa Sampaio Gonçalves

Carreiro $^{2}$;

Athena de Albuquerque

Farias $^{3}$

\begin{abstract}
The article proposes the discursion of what legal language is worth - its orality and its writing, support pillars of this field, which the Law Enforcement agents use in their profession to be well understood and thus win the case with the thesis presented in proceedings. What would be the characteristic of this profession? The need for conviction - a major tool of all those who take on the firm purpose of achieving justice, by right. There are understandings and theses in young scholars and others not so much, of those who are present in Warat, Koch, Bakhtin, and Tercero, who are fundamental to this study, who draw up understandings regarding the conduct and use of legal language, its current peculiarities and its traditions with a force of immutability, but that makes the legal work - teaching or militant, the differential of the operators that know and dominate and those who only observe.
\end{abstract}

Keywords: Legal Language, Orality, Writing, Teaching.

\section{Introduction}

The Higher Education Institutes in special attention Legal Area, they take to seriously their function of educate people that operated the legal order, without being able to leave far off what concerns the legal language.

Characterized as a mother tongue, the Latin language is something that carry the weight of the tradition, but that is usually little or hardly ever put into practice, leading to a teacher who dominates this language to one almost marking of antiquated and outdated.

A Magistrate ad hoc, what is same what it is lifted such an action is to tell him it to be a judge nominated for a determined processual end - very common in the cameras you arbitrate. And if the same operator of the right will come across a sentence where is his client put as the proper and immaculate accipiens, what the lawyer will do?

\footnotetext{
${ }^{1}$ Master degree in Education. Constitutional law specialist. Bachelor of Social Communication. Master Unissulivan Inc. Brazil. carreirog@hotmail.com

${ }^{2}$ Law Student. Faculty of Paradise - FAP. Juazeiro do Norte - CE, Brazil;

3 Lawyer. Procedure labor law specialist. University of Jaboatão dos Guararapes - UNIG. Recife - PE. Brazil. athena.farias@gmail.com
} 
The determination of the National Council of Justice advise that all, without exception, use accessible terms to anyone that comes to read the process - but it is known that some terms never stop existing and being used, like another two more traditional professions Medicine and Engineering, they also make usage of the appropriate terms between themselves, "translating" to the rest who aren't of the same field, but part of the context.

This study makes use of thematic works that deal with the proposal, with the intention of explaining the toughts of the theoreticians of the legal sciences, how they believe that it should be the process of education, formation and doctrine; that there is still an identifiable formalism in this area, which, without this "quality stamp", does not bring those who need their trust in the pursuit of their rights through the meanders of justice.

Nevertheless the Law Academies make use of the legal philosophy, the technical precision and the power of the speech, to reach the understanding of the parts in formation the academics and the parts involved on the lawsuit - the defendant and the author.

Without forget of the hermenutics of Law and of the dialectics in the Right, where everything takes place and the justice starts to exist and also from the precise chairs - with the confidence of which the terminology of the Canonical Law is an example well employee and the magistrate or judge pronounce the sentence: "Roma locuta, causa finita". (Rome spoke the cause it ended).

\section{Pre-legal Dialectics}

\section{Philosophy of the language in Mikhail Bakhtin}

Speaking is to express the thought, the wish to maintain dialog, of being heard - if it will be attended or not, it's a dialectic exercise where the arguments that more will weigh, be successful in the taken decision, which is said by Bakhtin (2006) to be "the destiny of the word is it of the society that he speaks. But there are several ways to study the dialectic evolution of the word". Which is the main objective of this article.

Such an exercise invites the reader to consider what the commercial knots that are made present in the human relations considers that "the enlargement of the appreciative 
horizon takes place in dialectic way" (2006) promoting an accented reduction in the distances between the human relations and soon the distances are narrowed - including the cultural background distances.

Bakhtin considers in the belief that the expert for "truth is not exactly in the environment, in a promise between the theory and the antithesis; the truth is over there, more distant, obvious an identic refusal both of the theory and of the antithesis, and constitutes a dialectic synthesis" (Bakhtin, 2006), when there is this a pillar to be properly arranged in the foundation of the academic formation of the legal science, which without such a sustenance would lack for confidence, for the whole society - represented by the faculty and by the pupils.

It is considered of the reason that every lawyer should be an orator par excellence like example that sets for the announcers of the radio-novel and in Orson Wells, who stopped a country in the United States of America of 1938, professional East promoted a collective conscience of the listeners who believed fully in the transmitted message. Taking the example above, it is noticed in the processual pieces what it follows:

To the speaker's awareness, language exists as a system of forms subject to norms; and it is only to the historian that it exists as an evolutionary process. This excludes the possibility of active association of the speaker's consciousness with the process of historical evolution. Thus, the dialectical conjunction between necessity and freedom is impossible, and even, so to speak, linguistic responsibility. (Bakhtin, 2006. p.110)

There are legal rules of language and formatting, a condition sine qua non to procedural dialogue, before in the pages and at a later time of hearings; nothing will walk and the case will pack up even before the judge has known there was something to read, understand, hear, understand again and judge.

\section{Fuza, Ohuschi, Menegassi: Language and the teaching}

Teaching is the action of transmitting knowledge on the part of the teacher so that the receiver / student understands the message and knows what to do and what not to do with the message received. 
Roughly speaking, there would be nothing more to discuss if there were no understanding that proper transmission requires an idem language, used for the education and formation of being; which arrives with little or no understanding - only using the desire to improve and broaden their understanding, for professional and personal training, thus meeting the expectations of themselves and those who live together.

This is what the author informs about "the domain of good speech was the objective of the conception of language as an expression of thought, not ensuring that the student had really understood the text." That is to be agreed.

\section{Basso: Orality and writing}

In the juridical universe and that in this being those who most need orality than writing, what are the operators of Criminal Law and Labor Law in the initial instances and the constitutionalists in the Superior courts - where are the procedural moments that take place for Defense Oral of the Thesis, as important as what was put on paper - procedural parts, those moments will be transcribed to the proceedings by the secretary of the hearing room.

The operator of the law must maintain consistency with regard to his or her speech and what before delivered to the court of the case, that "thus, through the presentation of different facets of the learning of the written language, it was tried to show that the school can not bet on a "Spontaneous learning" - since he was trained with audience simulation classes.

If one notices that the legal language is maintained or not, when jargon is still present "the subject on canvas", "with due respect", "in contestation of the lide" and so on, are some examples of language legal texts used in writing and orality, without changes or changes, but which are still already spoken in Portuguese - when they used to do it in Latin without the concern of being understood by others, even the parties were left out, having to rely blindly in his contractor - the lawyer, who asked, translated for the good understanding of all the lay people present. 


\section{Koch: The types of speech and the educational models}

Speech, it is the master of what is professed in the academy - all should leave the shyness if they want to be successful in the legal profession of any of the forms of toil. One seeks and finds in Koch's work three motivational items to consider in a didactic way.

First, the motivator, referring to the knowledge of specialists, when they say that in the technical language one has to demand their textual and oral production - whether in reviews, seminars, oral tests, written tests or even in procedural documents that have been compulsory since the 2nd semester. The academic becomes harvested by the web that involves the professional activity of which he chose to be productive in the society that lives.

It is commonly observed that law students use jargon proper to the Law Enforcement agents who have already passed through the pews and follow their professional trajectory and such reflexes are unnoticed by the user, but duly noted by their interlocutors, whether teachers, students, relatives or customers.

Secondly, there is an example of the students' abilities, the aims and objectives of the school: the teaching / learning processes.

Enabling the student to work as a professional is the objective of the academy, since he will carry for life the seal of the academy that he was part of, where he forged his knowledge and with this primary purpose the greater goals of the academy are being achieved, making himself present.

If the educational processes of the teaching / learning dichotomy are a challenge, it is the challenge in shared classes and seminars - where the academic is in a moment of discomfort before all, having to show what has come.

For the third shift - it adds knowledge and efforts for a coherent combination of this knowledge in the function of the objectives, where it is necessary to ponder about the characteristics of the didactic models proposed by the author of the work under study; such judgments take place in what is to "constitute the synthesis as a practical objective, aimed at guiding the interventions of teachers"; that they do so with the firm intention of getting the content presented in classes that are eminently interactive with students who use their knowledge to resolve doubts that still insist on survival.

In addition to being prepared to minimize the questions - always existing and welcome their existence, there is "evidence teachable dimensions from which the different didactic 
sequences can be conceived", didactic sequences that for the academic environment of the legal sciences are: Pigeonhole or PBL.

\section{The understandings of Tercio Sampaio Ferraz Junior: Technique, decision and domination in the symbolic function of the language}

Signs in language exist to indicate - mediate understanding about what was said and what was understood, having the function of being emblematic, of being distinctive.

As for linguistic signs sounds, phonemes are their intelligible base and these must be accompanied by signifiers, which without proper ordering can be exemplified in the basic question of procedural law: What is the piece itself? If it is not legal piece?

Thus we must start with the organization of legal discourses, which use the premises: meanings (definitions), meaning (meaning), symbol (allegory), semantics (interpretation of sentences), reference (code), ambiguity ), connotation (attribute), denotation (figure) and pragmatism (practicality).

Taking its own form, idem language and "language" that is peculiar to it.

\section{Guimarães: Bringing Herder and the language as propaying instrument}

The language as in the studies of Johann Gottfired von Herder - Test on the Origin of the Language, published in 1772 comes to treat the language like a propaying instrument of communication of the thought, this act that maintains inseparable the acts of thinking and speaking time what there is rational organization, where "the words radiate the capacity of communication for the most spacious do $\neg$ mínios of the life and of the force that the in $\neg$ tegram, they modify it and express it. (Herder apud Biderman, 2001).

In consideration of the statement we have that the Law and its own language are embarrassed, since the doctrine is eminently absolved by a language of its own and similar knowledge, and that such action flows into pronouncements of the legal field, made public by the principle of publicity of official acts, in its media - if it is not in the Official Gazette, it has no procedural value and what is not in the acts, is not in the world. 
The law has its own language and must follow, provided everyone understands its language - everyone, society; that it must know what the central idea is, that it must be translucent and intelligible in the transmission that will be given correctly, and that language will become, in the juridical field, "perfect to achieve its objectives, to obtain justice." (Guimarães, 2012).

The conviction, persuasion, the power to legislate, dialectics and judgment are conduits exercised roles - in recognition of the search donates pairs of litigants, academia and society finally has to understand that the language properly and well it lacks the proper application of its power to represent the litigant, without subterfuge; and there is no possibility of using jargon that can not achieve the desired justice - there is no "book on the table", with the intention that non-understanding would have led to legal victory, simply because the interlocutor does not know the language usage.

\begin{abstract}
The most important thing in a legal text is not the beauty of the sophistication of language, but the clarity, conciseness and precision that it presents, organized with logical reasoning and coherence, originating from a careful selection of relevant facts that make up the case. Clear language, therefore, is one that presents a high level of quality, without omission of words or without use of signs that are understood only by a determined group of people. (Guimarães, 2012)
\end{abstract}

The compendium is put on the table and the files are placed on the table - thus the argument is won, not with fallacious rhetoric - that can be described as language unworthy of justice, which should be public, with access to the legal branch and especially to those who they are not, their great majority; where this domain is almost the genesis of the dictatorship of para-legal or extra-legis ignorance (in the opinion of the operators of law), who take possession, who make of language a tool - a hereditary captaincy of the jurists, is the possession of knowledge.

Where one finds an example in the builders who mastered the technique of the trapezoidal cornerstone, it gave support to the rounded porticos, which like all tooling evolves by practicality and survival - it serves juridical justice, which is to be reached by all and thus idem to its language and understanding. 


\section{Karam: The language and the language of the power}

There is an ambivalence between what is being tended on the power of language and the language of power - where it is the conviction and the imposition; that one represents the eloquence of the orator, defender, jurist capable of the conquest to the justice by Law with its communication of two-ways, the language. The language of power represents the state responsible for good conduct in society, able to win the fair by the legal system, communicating the decisions taken and imposed.

Although there are limiting forms of action, language imposes limits more adequately, drawing perspectives for everyday law, limiting even the power that legal language insists on processing as a representative of the domain in the constitutional sphere "as a set of techniques and statements intended control and limitation of power: constitutional language is presented as an instrument in the service of the (good) end of the maintenance of political order and individual and social freedoms. " (Karan, 2015).

In spite of the subject in tele and in the incessant search of the more reserved feelings, one has in the processes narrations, as well as; Karan clarifies, when it comes to Law and Literature, which are:

(...) in court rooms, witnesses tell their version of the facts, experts certify the manner in which some actions were practiced, lawyers try to persuade jurors or toga judges, construct narrative plots, judges argue in their decisions the reasons that led them to prefer one narration to another. And here it is important to insist on two distinctions: the difference between narration of facts and narration of rules; and the difference between narration and argumentation. (Karan, 2015).

Although it has been treated, among others in the arguments of those who emphasize the Judiciary Power and those who make up the Legislator Power, to clarify understandings as to those that bring concreteness, using dialectics, narratives in language; with rational and legal argumentation to the decision made and these follow in the attitude of giving satisfaction to the electorate (play for audience) - disloyal.

Law and literature have the same unique and oratorical language that bring skills in the arguments to be used - these are the words of Karan, who also points to "doctrinal categories" - fictions and metaphors, aimed at a new allocation of principles and values according to the historical period and which is exemplified in the works of Willian Shakespeare influenced by 
the Gesta Romanorum (13th century), which influenced Cesare Beccaria, Rudolf von Jhering and Ariano Suassuna.

\section{Luiz Alberto Warat: Language, Fallacy and Power in the Legal Speech}

Law and it's language, Idealizing linguistics by connotation is to approach legal language. The premises for beliefs draw a panorama of street opinions, mixing them up, combining the technical and popular spheres; bringing to the Supreme Courts the "common sense of jurists" (Warat, 1984) with their legal-dogmatic understandings. Chäin Perelman exemplifies and Warat's words stand out:

Perelman, in his theory of conviction, did not take into consideration the fact that, besides the universal receiver, there is the institution as an indirect participant. In our society, most of the time, the conviction is generated not only by the issuer of a speech, but among other factors, also by the institution that, when re-enunciating it, redefines, adapts and allows the possibility of convincing. (Warat, 1984).

It is learned in Warat that Perelman evidences that legal language, in relation to its dogmas, support the exercise of interpretation of the problems of the proper topic of legal sciences.

They are an individual "of prescriptions, habits, topoi repertoire and stereotypes" who tend to present their transcendent homilies and divine estate - these understandings are found in the work where Warat tried to expose the search for a semiology of the power (Warat, 1981).

In addition to the "legal fallacies" found in this author, one has in the discourse - only so called, if it is persuasive and fundamental; since the exercise of the lawyers and in particular the activist this (persuade) is a constant exercise of argument, that is in the office with the client, whether in the corridors of the forums or in the courtroom, where the outcome will be with the delivery of the sentence - this one is persecuted from the first line presented in the distribution room of the judicial rods, so teaches Warat to say that besides the now clarified comes: 
relatively achieved. The relativity of rights is what determines and imposes the persuasive character of legal discourse (Warat, 1981).

\section{The power of the academic speech}

Self sufficiency and autonomy are own to the legal language. The teaching brings a weight of power, aiming to be convergent in the arguments and perspectives provided, tending to the densification and organization of what comes from legal signifiers.

It is in the power of the academic-legal speech that the faculty more provides it's elements and it's peculiarities, a few of topical one material (content) and others of formal topical one (process).

A deliberately unintelligible language is still found in the juridical-academic discourse, which will give the student the false impression of the superficial teacher's density - the ruse of those who are seen by cults, but unprepared for higher education and who by this conduct leads the student to mist and not to knowledge - by not distinguishing the precise moment of orality dense and well prepared in pairs, but out of synch with those who are not of the branch.

\section{Conclusion}

"Closed to a judge" this way, most of the processes end, following to analysis of the Judiciary and there is nothing that it is possible to do except the giving up of the process, but even this decision must be properly uttered in conviction language.

The protests for challenge piece must serve of vehicle appropriated for what the speech, which will overdo of proper legal language - both to situations are prepared for day by day in the environment academic and perfected in the professional, where from that one the forge separates the wanted and necessary product of the unnecessary ones.

\section{References}

Bakhtin, Mikhail. (2006). Marxismo e filosofia da linguagem. 12 ${ }^{\mathrm{a}}$ Edição, Hucitec. 
Basso, Fabiane Puntel. (2006). A estimulação da consciência fonológica e sua repercussão no processo de aprendizagem da lecto-escrita. 172 f. Dissertação (Mestrado em Educação) - Universidade Federal de Santa Catarina, Santa Maria.

Biderman, Maria Tereza C. (2001). Teoria linguística: leitura e crítica. 2. ed. São Paulo: Martins Fontes.

Ferraz Junior, Tercio Sampaio. (2003). Introdução ao Estudo do Direito: Técnica, Decisão, Dominação. $4^{a}$ Edição Revista e ampliada. São Paulo: Atlas.

Fuza, Ângela Francine. Ohuschi Márcia Cristina Greco e Menegassi Renilson José. (2011). Concepções de linguagem e o ensino da leitura em língua materna. Linguagem \& Ensino, Pelotas, v.14, n.2, p. 479-501, jul./dez.

Guimarães, Luciana Helena Palermo de Almeida. (2012). A Simplificação da Linguagem jurídica como instrumento fundamental de acesso à justiça. Publ. UEPG Ci. Hum. Ci. Soc. Apl. Ling., Letras e Artes, Ponta Grossa, 20 (2): 173-184, jul./dez. 2012. Doi: 10.5212 Publicatio Huma. v.20i2.

Herder, J. G. (1987). Ensaio sobre a origem da linguagem. Tradução José M. Justo. Lisboa: Antígona.

Koch, Ingedore Grunfeld Vilaça. (2003). Desvendando os segredos do texto. $2^{\mathrm{a}}$ ed. São Paulo: Cortez, 2003.

Vespaziani Alberto. Tradução de André Karam Trindade. (2015). Poder da linguagem e as narrativas processuais. Anamorphosis - Revista Internacional de Direito e Literatura v. 1, n. 1, janeiro-junho.

Warat, Luis Alberto (1984). O Direito e sua linguagem. $2^{\mathrm{a}}$ versão. Sergio Antonio Fabris Editor. Porto Alegre, RS.

Warat, Luis Alberto. (1981). À procura de uma semiologia do poder. REVISTA N. ${ }^{\circ} 3$. Ano 2 - $1 .^{\circ}$ semestre, p. 79-83.

Warat, Luis Alberto. (1985). As falácias jurídicas. Seqüência. UFSC, Florianópolis, SC, Brasil, ISSN: 2177-7055

Warat, Luis Alberto; Roca, Leonel Severo. Cittadino, Gisele. (1980) O Poder do Discurso Docente das Escolas de Direito. Comunicação ao "IV Encuentro Nacional de la Metodologia de la ensenanza del Derecho". México - Durango - Novembro. Rev. Seqüência, Ano I, $2^{\circ}$ Semestre. pág. 146.

How to cite this article (APA):

Barros Filho, Geraldo C.; Carreiro, Larissa S. G.; Farias, Athena de A. (2017). Reflections on Legal Language. Am. In. Mult. J., Oct. 2 (3), 17-25.

Received: 8/12/2017;

Accepted: 8/30/2017. 